\title{
WHAT WE SHOULD KNOW ABOUT GENETICALLY MODIFIED FOODS
}

\author{
R. Akromah \\ Department of Crop Science. Faculty of Agriculture, \\ KNUST, Kumasi. Ghana
}

\begin{abstract}
Most of us know very little about the way our food plants are grown and are far removed from the factories where they are processed. All we care about is that our food should be wholesome, nutritious and tasty. Critics of crop biotechnology are of the opinion that potential ecological and food saffety disasters are looming on the horizon because genetically modified (GM) crops have entered the food chain. Alarmists have introduced emotionally charged terms into the debate and speak of 'frankenfoods' and 'genetic pollution'. Issues of food safety and food sufficiency are extremely important to the general public and all need to be adequately informed to be able to take decisions on whether or not to allow (iM foods into the food chain. In this paper, I present basic facts for the general public and invite other opinions on the topic and suggestions for the Way Forward in a developing country like Ghana.
\end{abstract}

\section{INTRODUCTION}

Opponents of GM foods claim that the risks of introducing genctically modificd crops into agriculture will be 'super wecds' and 'super bacteria', the appearance of unknown toxins and allergens in our foods, paralysing crop losses and extensive ecological damage. These claims are however not based on facts or evidence. Before I draw you into the Bio-safety concerns of the 'green' organisations and 'consumer' groups, let' me first provide a few vital information.

\section{Conventional Plant Breeding}

Traditional plant brecding procedures are based on manipulation of genes and chromosomes through sexual reproduction in whole plants. The procedures were developed from Mendelian genetic principles and were cxpanded with developments in cytology, polyploidy, mutation induction, quantitative genctics, hetcrosis, male sterility and related areas. Movement of genes by cross-pollination is the principal method of creating new gene combinations in plants by conventional breeding. However, in order to increase the choice of genes, various methods have been developed to hybridise plants from different species or genera (often called 'wide hybridisation'). The transfer of genes in wide hybrids usually involves several thousands of genes, when we are really interested in only one or a fow genes that control the disea.e resistance or pest resistance character we want. The transfer of $1000-4000$ genes is a consequence of the way genctic recombination works during meiosis. The difficulty this prescnts to the plant breeder is that unwanted plant characters are often transferred as well. Sometimes, the gene donor species contains toxins or has weedy characteristics. Because of this, plant breeders have developed testing and cvaluation procedures which takc many years, in order to screen out the plant lines that have undesirable characters. 


\section{Modern Plant Breeding}

In recent years, a technology for genetic manipulation at the cellular level has emerged, which has the potential for supplementing traditional plant-breeding.procedures. The new technology has made it possible to isolate genes from a wide range of living organisms, and to insert them into most of our crop plants. There are two main ways of inserting genes: the bacterial method and the gene gun method (Cocking, 1990). In the first method, molccular biologists working with plants commonly use DNA vectors to move genes from one organism to another. The best developed DNA vector is a plasmid of the bacterium Agrobacterium tumefaciens. In nature $A$. tumifaciens infects plants and causes tumors called crown galls. The tumors are induced by the plasmid, called the Ti plasmid (Ti for tumorinducing). The Ti plasmid integrates a segment of its DNA, known as T DNA, into the chromosomal DNA of its host plant cells. Researchers have developed ways to eliminate the plasmid's disease-causing properties while maintaining its ability to move genetic material into plant cells. Foreign genes can be inserted into the Ti plasmid using recombinant DNA techniques. The recombinant plasmid is either put back into Agrobacterium, which can then be uscd to infect plant cells growing in culture, where it incorporates into the plant's chromosomes. Then, taking advantage of the capacity of those cells to regencrate into whole plants, it is possible to produce plants that contain and express the forcign gene. and pass it on to their offspring.

In the gene gun or particle gun method, rescarchers bathe microscopic pellets of gold or tungsten in DNA that has the desired trait. The coated pellets are inserted into plant cells with the special device. As the pellets pass through the cells, some of the DNA coating is left behind, mixing with the plant cell's DNA to add a beneficial trait. This makes it possible, in principle, to introduce a wide variety of genes and to modify crops in novel ways. Some of the crop characteristics undergoing genetic modification, as listed by Dalc $(2000)$ arc:-

- Pest resistance

- Resistance to viral, bactcrial and fungal discases

- Oil, starch and protein modification 10 provide sustainable supplies of raw matcrials for biodegradable plastics, detergents, lubricants, paper making and packaging: also. improvements in baking and brewing qualitics

- Herbicide tolerance, to enable certain crop varictics to tolerate specific herbicides and, in many instances, reduce the number of herbicide applications to achicve effective weed control

- Plant architecture and flowcring including plant height, flowering time and flower colour

- Reduction in seed losses through shedding at harvest time

- Modification in fruit and tubcr ripening and storage; rescarch on potatoes is likely to reduce dependence on the use of anti-sprouting compounds applied to stored tubers

- Increased tolerance to environmental stresses, including cold, heat, water and saline soils

- Increase in the ability of certain plants to remove loxic metals from soils (bioremediation), c.g. on mining ficlds

- The climination of allergens from certain crops, c.g. rice and groundnuts

- The enhancement of vitamins, mincrals and anti-cancer substances

The production of pharmaceutical substances, cg. anti-coagulant compounds, edible vaccines.

The underlying principle is as follows:

All DNA has the same basic structure. In fact from earthworms to human beings, we are all struclured under the genetic code, which conlains the four letters: A C G T (for Adenine, $\mathrm{Cy}$ - 
tosine, Guanine and Thymine, respectively). The differences up the ladder lic in the manner in which the letters are arranged into sequences that code for information that translates into amino acid chains and hence proteins, and also the sizes of the genomes. The prokaryote lischericia coli, for cxample, has a genome consisting of $4.5 \mathrm{mil}$ lion base pairs (Berg and Singer 1992), which is a reasonable estimate given that there are about $4000 \mathrm{E}: \mathrm{coli}$ genes with an average size of 1000 basc pairs. In comparison, many cukaryotic genomes have been found to have a thousand times as much DNA - 6 or 8 billion base pairs per diploid cell, equivalent to 3 to 4 billion base pairs for a complete haploid genome. Given that the average gene is 1000 base pairs long, only 100 million of the genomes 3 to 4 billion base pairs will be expecied to be in genes. The bulk of the cxcess DNA in eukaryotic genomes is now known (thanks to the human genome and other similar projects) to be in introns and part is in long stretches of additional noncoding DNA between genes. Thus while genes are stretches of DNA, not all strectes of DNA are functional genes. The complexitics show in the number of genes and in the sizes of the genes. The Designer has so cleverly separated cach gene with a START and STOP codon as well as repetitive sequences that do not code for anything. otherwise known as redundant DNA to scparate onc gene sequence from the other.

Gene analysis has revealed that in the course of cvolution, some organisms have exchanged DNA with each other; one organism passing a few genes to another organism. Plant molccular biologists now use this natural gene exchange mechanism to insert new genes that carry valuable agronomic traits into the genome of crop plants. The new plant then becomes a genetically modificd (GM) plant. The technique is also referred to as genetic enginecring (GE) or genetic improvement (Gl).

Presently only a few genes are inserted at a time; in the future, rescarchers will be able to insert scgments carrying multiple genes. Scientists don't know exactly where in the genome a gene lands, but this is usually not important because the genome secms to be rearranging itself anyway. Furthermore, if the DNA lands in an unsuitable place that makes the plant less useful or incdible. then those plants will be eliminated in the breeding process.

\section{Some benefits from Genetic Engineering}

Biotechnology has been able to use the above methods to create many improved crops. For cxample, insect resistant crops, reducing the need for pesticides, delayed ripening in tomatoes, and virus resistance in potatocs. Let me take one popular recent improvement to help clarify the technology: Bacillus thuringiensis, $\mathrm{Bt}$ for short, is a bacterium that produces a protein called Bt toxin; this protcin pokes holes in the guts of insects and insect larvac that ingest these bacteria. First discovered in 1902, Organic farmers use this natural pesticide to keep the population of some insects under control. Scientists at Monsanto Company's Life Sciences Rcsearch Centre in St. Luis, USA, have taken the Bt gene and transferred it into cotton, maize, and potatocs, so that every cell of these plants now makes the Bt. protcin. Only lepidopteran (butterflics and moths) larvac that feed on the roots, stems, leaves or secds of such crops are doomed because Bt. produces a protcin that disrupts the digestive system of targeted insects, while remaining harmless to other insects, pcople, birds and other animals. Farmers are happy because they do not have to worry about pesticide residues. More importantly, other beneficial insects are not killed by insecticide sprays. Studics have shown that ficlds of Bt crops have more insects and a greater diversity in insect species (Halfhill et al., 2001).

In the not too distant future, varietics of crops like wheat and corn that have been enginecred to produce storage protcins containing a mix of amino acids more suitable for the human dict 
will enter the food chain. At present, more than 30 different crop plants developed with recombinant DNA techniques are being tested in field trials around the world (Johanson and Ives, 2001).

Current information has it that in the not too distant future, there will be a shift from today's method of immunising children against the six killer diseases. Instead of letting our children go through the trauma and pain of the injections, molecular biologists are introducing the vaccines into fruits and vegetables such as tomatoes, apples, bananas and carrots. The beauty of these target crops is that they can be taken raw without cooking. Therefore tomorrow's children will only have to be fed with these fruits and vegetables in their normal diets and get the additional benefit of becoming immune to the six childhood killer diseases. At the University of Hawaii, Researchers have modified a biochemical pathway in coffee to stop the natural production of caffeine in the crop. They did it by introducing the antisense gene for the enzyme xanthosine-N7-methyl transferase, the first enzyme in the pathway to caffeine synthesis (Johanson and Ives, 2001). This natural process of decaffenating coffee berries will allow us to maintain the aromatic properties that are otherwise lost in the artificial process of de-caffeination and will also allow people with hypertension go back to their favourite early morning cup of coffee.

Safety issues on GM crops and how to deal with them

All advances in science and technology bring new opportunities, but also responsibilities to manage them carefully for the benefit of mankind and the environment. Genetic modification is no exception. There is international agreement on the need for safety assessments, in addition to the standard tests used for the production of conventionally bred varieties. There is international agreement that GM crops should pass through a safety assessment process. This involves re- sponding to a series of questions aimed at determining the possible impact of the modification on human health and the environment. A summary of the main questions that are considered during safety assessment and to which the new organism must satisfy include the following:

- What is the function of the gene in the donor organism?

- What is the effect of the introduced gene(s) on the modified plant?

- Is there evidence of a change in allergenicity or toxicity?

- Will there be non-target effects on friendly organisms within the environment?

- Is there a change in the plant's ability to persist in agricultural habitats (e.g. weediness) or to invade natural habitats?

- Can the introduced gene be transferred to other plants (e.g. by pollination) and what will be the likely consequences?

Molecular biologists (or genetic engineers) are expected, as a rule, to satisfy the government agency responsible for ensuring the safety of consumers and the environment by ensuring that the crop or organism intended for release checks satisfactorily for all the questions listed above before a permit for release will be granted. Therefore there is a long period of rigorous testing before a new GM crop is put forward for consideration for release as a variety in agriculture. What is absolutely important is for the government agency that approves of the release of a crop to be well-equipped and have the expertise to conduct independent assessment of all GM crops before they get into farmers' hands.

The reality is that some Activists do not have the patience to allow Scientists undertake the rigorous testing required to critically assess the new varieties. In the developed countries (particularly in France and the United Kingdom), we read about some Activists sneaking in at night to de- 
stroy GM crops that are being tested in experimental plots. in protest of the new science. Scientists are now having to raisc high sccurity fences to protect transgenic crops being evaluated. This adds to the cost of developing such crops which will cventually be passed on to the farmer as unit seed price.

In deciding whether or not to accept a GM food, we should be concerned about the characteristics of a food, not the method used to produce the food. The World Health Organisation (WHO), the Food and Agriculture Organisation (FAO) and the Organisation for Economic Cooperation and Development (OECD) have jointly advocated for the application of the Principle of Substantial Equivalence to the safety evaluation of foods or food components from plants derived by modern biotechnology (FAO/WHO, 1996). The goal for this principle is to ensure that the GM food must be as safe as traditionally bred varicties and foods. Thus the new biotech crop should, among other considerations, be substantially equivalent to other commercial varieties in key nutrients as well as naturally occurring antinutrients and toxicants. The agency responsible for biosafety must perform proximate analysis (protein, fat, ash, fibre, sugar, and moisture) as well as calcium and phosphorus measurements and amino acid and fatty acid composition, for comparison with those of conventionally bred varieties.

Biotech foods reviewed to date have been found to be comparable, or substantially equivalent, to their traditional counterparts aside from the defined difference(s) conferred by the novel trait (s).

\section{Conclusion}

To conclude, the author of this paper belongs to the School that argues that biotechnology will boost food security for the world's growing population by raising sustainable food production. It will benefit the environment by reducing the need for new farmlands, irrigation and pesticides. It will also provide better medical treatments and vaccines, new industrial products and improved fibres and fuels. The author however maintains that while modem biotechnology may have great potential, it must be developed and used with adequate safety measures, particularly for human health and the environment.

\section{REFERENCES}

Cocking, E. C. (1990). All sorts of plant genetic manipulation. In: G. W Lycett and D. Grierson (cds.), Genctic Engineering of Crop Plants. Proceedings of the $49^{\text {th }}$ Easter School. Butterworths Publications, London. Pp. 1-12.

Dale, P. J. (2000). The GM debate: science or scaremongering? Biologist, 47(1): 7-10.

FAO/WHO, (1996). Food and Feed Safety: the products of plant biotechnology. Report of a joint FAO/WHO consultation on Biotechnology and Food Safety, Sept. 30 - Oct. 4, 1996, Rome.

Johanson, A. and Ives, C. L. (2001). An inventory of agricultural biotechnology for the castern and central Africa region. Technical Paper No. 114. SD publication scries. USAID.

Halfhill, M. D., Richards, H. A., Mabon, S. A. and Stewart, C. N. Jr. (2001). Expression of GFP and Bt transgenc in Brassica napus and hybridization with Brassica rapa. Theoretical and Applied Genetics 103 (5): 659-667. 